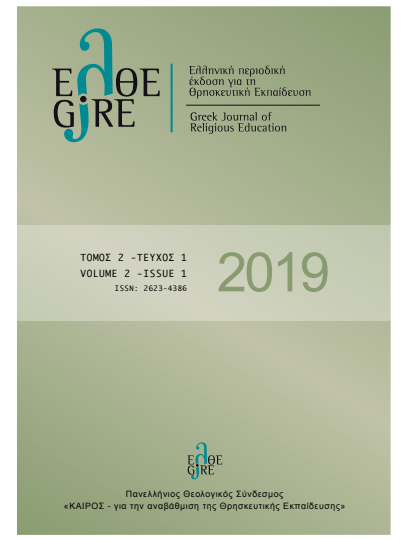

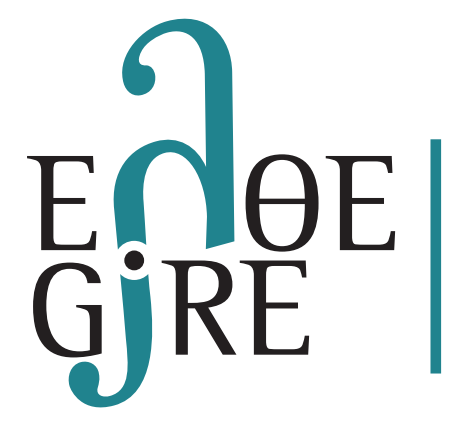

ISSN: 2623-4386.

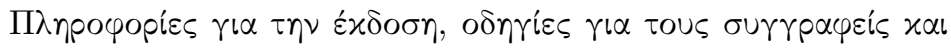
$\tau \eta \nu$ u $\pi \beta \circ \lambda \eta \dot{\alpha} \alpha \vartheta \rho \omega \nu$ / Publication information, instructions for authors and subscription information: http://www.gjre.gr

\title{
A reflective RE teacher training in Greek context /

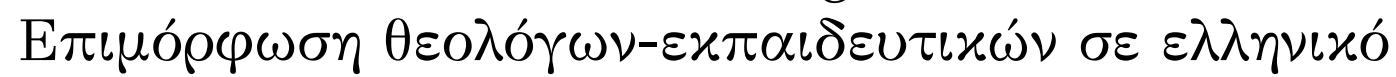

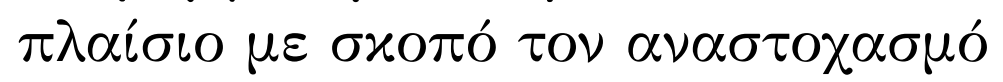

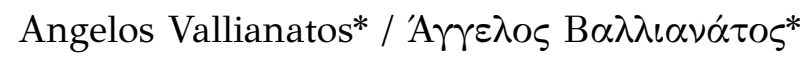

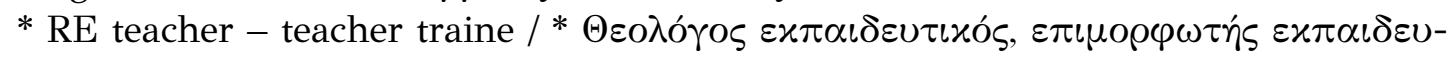
$\tau \iota x \omega \dot{\nu}$

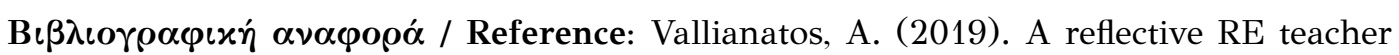

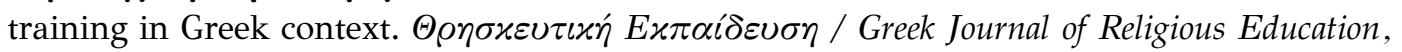
2(2), 47-59, DOI: $10.30457 / 031120194$

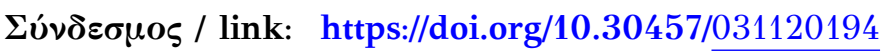

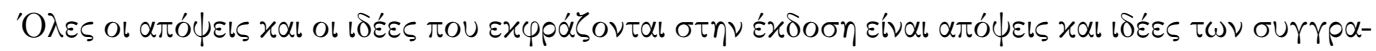

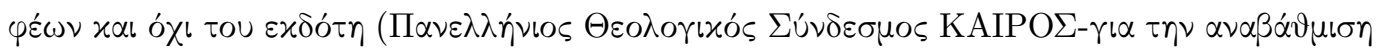

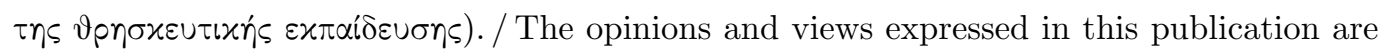
the opinions and views of the authors and not of the publisher (KAIROS - Greek Theological Association for the improvement of the Religious Education).

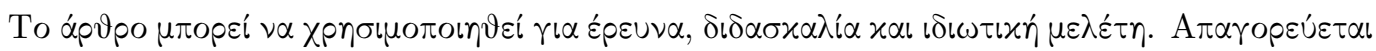

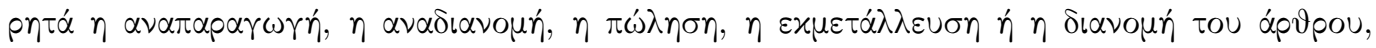

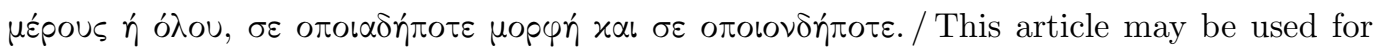
research, teaching, and private study purposes. Any substantial or systematic reproduction, redistribution, reselling, licensing or distribution in any form to anyone is forbidden. 


\title{
A reflective $\mathrm{RE}$ teacher training in Greek context
}

\author{
Angelos Vallianatos*, \\ * RE teacher - teacher trainer, avall@sch.gr

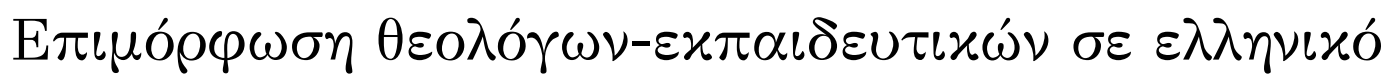

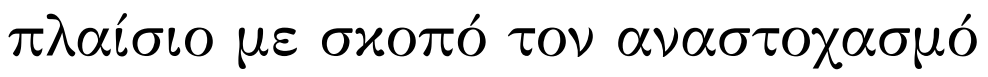

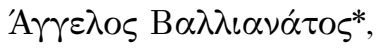

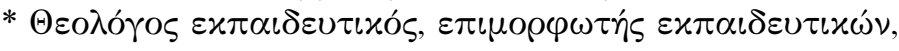

\begin{abstract}
Religious Education (RE) curricula in Greece, have changed from catechism to literacy. Greek society -and the RE stakeholders- have not necessarily followed $\mathrm{RE}$ aims changes with the same pace. Following the absence of formal in-service training, RE teachers form a personal teaching theory based on personal conceptions, often affected by the controversy between teaching from, about and for religion. A solid teacher theory is needed to safeguard RE teachers from influence and ambiguity, in order to meet the educational needs of students in the Greek, rapidly changing society.

In this article, in order to propose the principles of transformative knowledge, as a suitable tool for teacher training addressed to RE teachers themselves, meeting the need of strengthening their teaching theory, we conducted a single session training research on $8 \mathrm{RE}$ experienced teachers, using arts, investigating participants answers on the purpose of the RE teaching from the RE teacher's point of view. The research shows the need of strengthening RE teachers' teaching theory, as well as further research for deeper investigation of the special training needs of $\mathrm{RE}$ teachers in Greece.
\end{abstract}

Key words: Religious Education, teacher training, transformative knowledge, education through arts

\section{Religious Education in Greece}

EThe aims of the RE in Greek educational system are depicted at Greek Constitution (article 16, para. 2) and the relevant legislation of the Greek Ministry of Education (Law 1566/1985). The last curriculum in force was introduced at the beginning of the school year, 2017-18. It is significantly different from the previous one (2003), and extremely different from the ones that it replaced $(1977,1985,1996)$, both content and method wise.

Up to the '80's, Religious Education in Greek school was catechetical. In spite of 
the changes that were done for the democratization of Education, after the military government of the "Greece of Greek Christians" (1967 - 1974), RE kept on dealing exclusively with the teaching of Christianity and especially of it's Orthodoxy, assisted by the lessons of History and Language. Among the aims of RE curricula at the 1977-78 law is mentioned to be: "the revelation of the truth of Christ about God to the creation and the human being, the initiation of students to the salvation offering truths of Christianity through the orthodox faith and life, the awareness of the historical way of the Church and it's offering to the world, the experience of the truth of the Orthodox Christian faith at the certain circumstances of the student's everyday life, so that he could improve "through wisdom, age and grace and become a perfect man, according to the measure of those who follow Christ".

Just on 1980, the board of directors of the teachers' Union was brought to court, accused of "insulting the dogmas of the prevailing religion", because at it's magazine

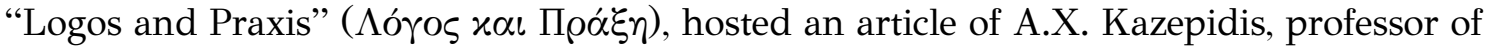
Philosophy of Education, titled "the ideological confusion and the dogmatic saturation of youth in Greek education" (1979). The professor there commentates that the teaching of Christian dogmas cannot stand towards an objective public analysis and criticism, constitutes an unconsidered dogmatic saturation of the Greek youth, which is mainly responsible for the confusion that predominates Greek education. The court's judgment was exculpatory, showing however the mainstream logic of that period.

In 1985 curricula, the general aims of RE foresee that the students should: "Be informed for the texture of the religious phenomenon, get to know specifically the Christian faith, especially Orthodoxy and take a responsible stand, and, make a good use of what the lesson offers in order to cultivate their ethos and personality, sensitize towards contemporary social concern and be helped to take an active position".

This significant change becomes even more by the curriculum change of 2001-3. As it is referred to the general aims of RE, the content moves away from it's catechetical character and keeps a mild mono-religious type (Koukounaras Liagkis, 2018). In parallel, a more pedagogical approach was introduced. Essays to be learned were shortened; sources (texts, excerpts, pictures) were offered to work on during lesson.

RE in Greece has a new curriculum since two years (2016-7) that changes the way that it is taught in Greek schools. The new curriculum for Primary School and High School (Years 9-15) was firstly published at 2011 and was piloted at a number of schools in different parts of Greece. It is a process based curriculum (Stenhouse, 2003[1975]) that a) unfolds the religion content in thematic units of four to seven twohour lessons, b) the teacher develops his/her scenario on expected learning outcomes that are proposed by the curriculum and he/she should adjust them to be attainable depending on the students in each classroom c) teaching is based on experiential and cooperative learning methods and techniques and d) instead of a traditional textbook, the students use in the lesson religious sources, given to them as material files books (a corpus of educational material that can be selected in teaching). The aims of the curriculum are mainly focused on religious literacy (Wright, 2004; 2007) using 'learning about' and 'learning from' religion approaches (Grimmitt, 1987; Jackson, 1997) in an innovative "mix" that is sometimes critisised. (Koukounaras Liagkis, 2015). 
The official implementation of the curriculum (2016) has caused big public debate. The issue has taken a large front-page part at newspapers for weeks. Bishops of the Greek Orthodox Church have publically condemned it as transmuting the pure Orthodox character of the lesson (Chrysopoulos, 2016a). One of the theologians union denounced a conspiracy of other religions intruders that aim to alienate the Christian Orthodox identity of the Greek population, threatening at the same time the ones that are using the curriculum to be prosecuted for proselytizing children to the new age "pan religion" (Vassalou, 2016). On the other hand, the official announcements of the ruling political party have announced that the relation of the Church and State has to be directed by clearer roles, towards a secular European condition. At the same time, other criticism complained that RE content still remain catechetical, aiming to favor the prevailing Orthodox Church in Greece (Chrysopoulos, 2016b). A bishop of the Orthodox Church, a theologian union and two parents have brought the Ministry of Education to the Greek Council of State. Decision condemning the curricula has been issued (660/2018 and 926/2018), a second one being waited, because the Atheists organization in Greece and others accuse it to be confessional and mono religious. The public debate and the political pressure has caused the change of a Minister of Education (2017), the conflict of church and state generated for the first time in Greece a joined committee that discusses about the content of RE, trying to find a mutually accepted way. During that period (2017-18) the exemption percentage has not changed, even if several Bishops as well as the Panhellenic Union of Theologians has issued an application addressed to Christian Orthodox families, members of the Orthodox Church, proposing to save their children from their exposure to the dangerous new RE curricula, while at the same time calls RE teachers to declare that they deny to use them. (PETH, 2018).

Even if on a legislative level changes happened, they didn't occur to the teaching of $\mathrm{RE}$ teachers by the same pace. The ministry of education is used to believe that it's duty ends to the issuing of laws. No formal in-service teacher training exists in Greece, nor teacher training institutions or a culture of training among the vast majority of teachers.

It is interesting to note here that this doesn't mean that the content and the model of RE actually didn't change. Most of the RE teachers in Secondary Schools (75.94\%) followed the changes foreseen by the curricula, mostly as a need deriving by the changes of Greek society as depicted at their students, regarding their educational needs, as experienced in the classroom.

\section{The religion teacher competences in Greek educational system}

Class teachers teach RE in primary schools, regardless if they had any RE course during their undergraduate studies. In secondary education, those who are appointed as RE teachers have to have a degree from a Greek School of Theology University or an equivalent recognized University from abroad. Faith, religious or non religious preference are not preconditions to attend a School of Theology. During their studies, RE teachers, contrary to a common misunderstanding, are not catechized at the Greek Orthodox religion. Schools of Theology offer a broad variety of lessons dealing with the Orthodox Church and Christian Churches, different religions, biblical studies but also elements of pedagogics and didactics, sociology, philosophy and literature. Hereunder, 
School of Theology graduates have the education and the competences to teach RE as described by the Greek educational system in its latest verse, but also at other European countries.

RE teachers in state high schools are appointed and paid by the state. In order to be appointed as RE teacher in high school, no religious statement or affiliation is needed. No church and no religion is involved at this procedure.

Religion lesson in Greece is equally, one of the school subjects, without any specialty other than its content. It is defined by its pedagogical and teaching principles like all other subjects. Nevertheless, there is a perception in society that RE is the extension of the Orthodox Church at school and RE teachers have to introduce students to the Christian Orthodox Church. That has a negative impact on RE teachers' position in schools since they can be characterized positively or negatively, according to the religious assumptions and the feeling of the school director, the colleagues, or the parents.

\section{The training needs of RE teachers}

Religion teachers in Greece today are called to implement a new curriculum that is oriented in religion literacy, based on constructivism, offering choices of methods and tools of new pedagogy. In parallel, they live in a society that changes in slower pace than what the educational needs of students demand. They have to face traditional conceptions about the existence and the role of the prevailing Christian Orthodox Church, which influence the opinion about the RE of a powerful part of society. At the same time they have to combat with the relation of their own perceptions about the role of their personal religious beliefs and its link to their teaching.

A clear knowledge of the legislative framework concerning the subject-this is not self-evident in Greece- is one of the training needs. If not, RE teachers are exposed to surrounding ideas and opinions. This public atmosphere, regardless their teaching and/or religious assumptions or beliefs, form a condition towards which either they submissively obey, or fight, or surrender, usually adopting an attitude of indifference while diminishing their professional performance.

The majority of RE teachers in Greece seem to have accepted the current RE curriculum. Yet they find it difficult to apply cooperative teaching methods, mostly due to being used to teach in a teacher-centered way. It is not rare that Religion Lesson is taught either by a lecture or a strictly guided discussion, where the teacher gives or checks the right answers. There are many teachers that feel that they bare and transmit the one and only "knowledge" that students need to know. There are teachers who believe that they can 'transfer' to the students their own religious experience (Stavropoulos \& Koumaropoulos, 1998). It can't be accidental that in such cases the teacher covers him/ herself under a strict implementation of behavioral rules. Teaching methods appears to be crucial to RE teachers training.

Nevertheless, apart from a sufficient knowledge of legislation and teaching methods, that teacher training can cover, the urgent need for religion teachers seem to be the orientation of training towards teachers themselves. Their personal teaching theory 
cannot safeguard that they feel competent and safe at their teaching action (develop and implement a lesson according the curriculum and students' needs), critically approaching the events that follow the rapid change in Greek society, so that they don't blur the dedication to facilitating the students educational religious literacy needs.

\section{Transformative knowledge as the background and starting point for a religion teacher training}

Traditional teaching theories and practices are proven more and more outdated and insufficient nowadays. The fast way that society changes and the new technological means that students use in their daily life create new necessities. Behavioristic interpretations of learning, knowledge and teaching cannot be anymore functional in today's school. Students educational needs becoming more and fast different, create a growing gap between content and methods that seemed to work some decades ago. Acording to Mezirow, this creates a lack of harmony between one's contemporary experience and the system of values and attitudes that he/she has. Even if Mezirow presupposes that at such times, one strives to learn more about his/herself and the world, this seems difficult to happen by itself, mostly due to the numbness that this luck of harmony creates in times of rapid changes and all kinds of crisis. At the same time, it proposes that transformative learning can be a handful tool for teacher training oriented to the teachers themselves. Furthermore, if as adults today they are confronted by the statement that a conception and/or a practice that was efficient till yesterday, fails to offer a solution today, especially if it is needed to confront a new sudden experience, a «disorienting dilemma» that has to become understood and confront able, while at the same time it works as a good starting point for critical thinking in order to clarify if what we used to believe are still valid and are functional to our practice or if there is a need to reconsider and position our values, conceptions and attitudes towards the new facts and experiences (Mezirow, 2000).

From the four ways that knowledge happens, (ibid), the two first already have means to be found in the Greek RE curricula: «the process of existing reference frameworks» are well known by RE teachers. Even if the lesson curricula have changed repeatedly, up to the last change there is no significant or dramatic change at the learning process offered at schools, content and method wise. «The knowledge of new ones» are offered by the new curricula. Parallel to the laws describing them, teachers have handy tools, named «Teachers guide», where they can find the theory, the method and practical examples that illustrate the change in detail. A large number of implemented examples and ideas by religion teachers can also be found online. The need lays on the "transformation of opinions or the transformation of conceptual habits", giving religion teachers the possibility of acquiring and/or strengthen a teaching theory that will be based on the knowledge and choice of an educational philosophy, clear teaching strategies and to deal with issues concerning their personal positioning towards the relation of their personal religious condition and its relation to their teaching. 


\subsection{An attempt to develop and test the method in RE training needs}

In order to further research on the need to orient religion teachers training towards themselves as teachers, and especially the need to strengthen their teaching theory, an experiment religion teachers training activity was developed and implemented in January of 2019, using an activity from transformative learning through aesthetic experience method (Kokkos \& associates, 2011).

Target group: Eight RE teachers, randomly selected, four female and four male, having teaching experience more than 5 years at schools, that have participated in teacher training about new RE curricula, and also participate in the mentoring project of the school of Theology at the university of Athens'. The teachers already have trainer's trainee's relation with the researcher throughout the last three years, because he has participated to their training and has followed the mentoring project.

Aim: The aim of the case study was the research on participants personal views towards RE, under a single question: "What is the purpose of the RE teaching from the RE teacher's point of view?"

Method: A 3 hours training module using an activity from education through arts (Kokkos \& associates, 2011), adapted at the certain framework and the aims of the activity.

The main outcomes of the training were that art works helped participants in deepening and widening their conceptions about the role of RE from the teacher's scope and helped personal retrospection and discussion about the personality of the teacher, its connection to the different teaching methods and the link to the need of a personal teaching theory

The work of arts selected were

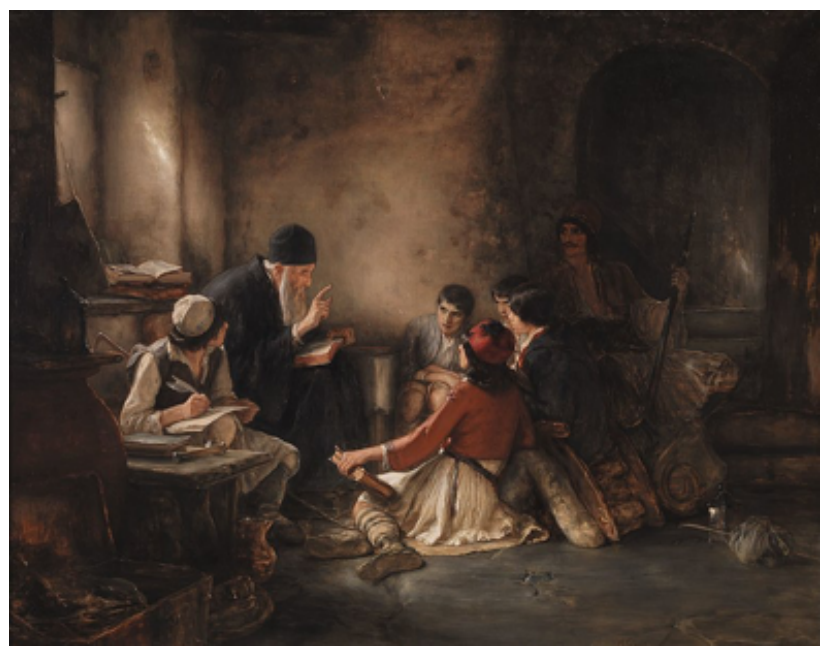

“The hidden school” painted by Nicolaos Gyzis at 1885 and

1 During the mentoring project teachers are offered training about the curricula, educational and teaching methods, mentoring techniques. Teacher students visit their mentor school, observe lessons, cooperate with him/her, participate in teaching and eventually teach a thematic unit. 


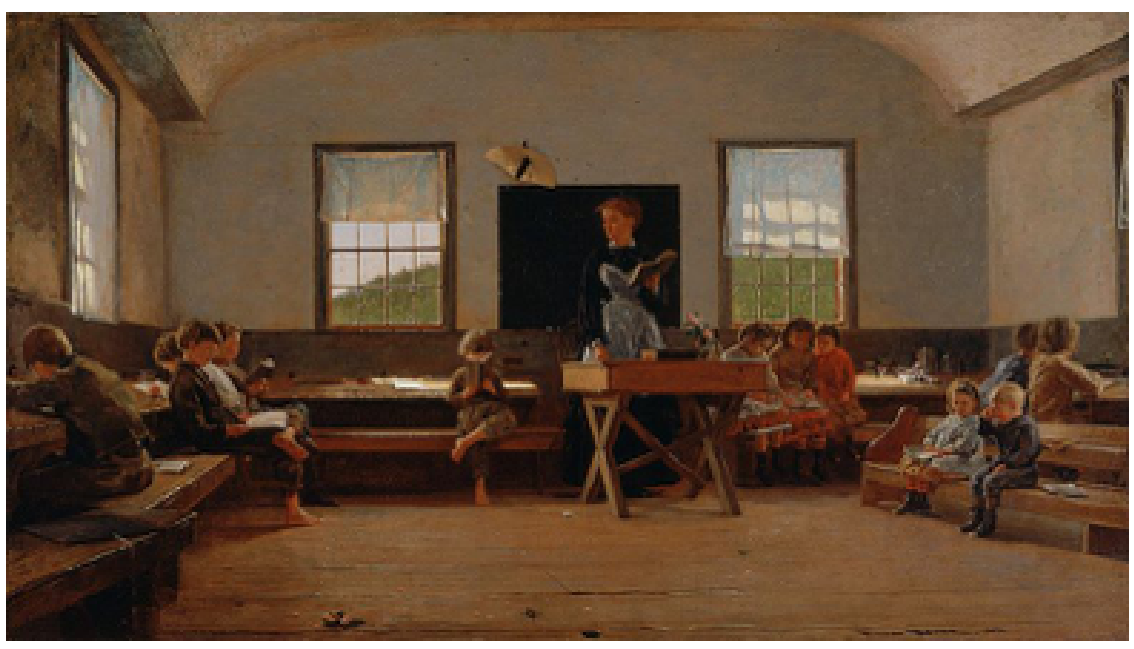

“The Country School” painted by Homer Wislow at 1871.

The paintings were selected because they are authentic art, drawn at the same period of time in different educational conditions (Greece and the USA both after war) both stimulating the main question of the activity.

The "hidden school" painting, a very well known art work in Greece, was also selected because it presents the role of the Church during the 400 years Ottoman occupation, as depicted in History and Religion lessons at school. Even if nowadays the number of priests that work as teachers is small, the painting presents an underground feeling of "normality" in connecting the Church or the "Greek Orthodox cultural identity" to education via it's religious dimension.

Moreover, the two paintings were chosen by the trainer as presenting two different lesson methods, in order, at a third stage, to create a possible "disorienting dilemma", if some elements of their current understanding included in their personal theory could be found to be insufficient or incorrect, creating a process of questioning their understanding and views and entering the transformative learning process (Mezirow, 1991).

Activity process: At the beginning of the activity, participants were asked to answer to the main question. Every participant chose a three-digit code; his or her answers were anonymous. The group studied the first painting, using the "3 questions" (what do I see, what do I think about it, what do I wonder) method of artful thinking, a program, developed at "Harvard Project Zero", that helps teachers to connect art with the curriculum, as a tool to integrate students' thinking dispositions.. After that, participants answered to the same question on a different piece of paper, the answers were collected. Then the group studied the second painting, using the Perkins ways of better looking (time for looking, broad and adventurous looking, clear and deep observation, reviewing the work fluently, marshaling all discoveries) (Perkins, 1994). Following this, participants answered to the same question for third time, their answers were collected. During the discussion on the art works, the trainer kept analytical notes on participants' reactions. The answers were given to two independent researchers that didn't participate to the activity and were not informed about the activity process, in 
order to address the differences between the three answers of every participant. The researchers worked on the material separately. Moreover the researcher acted as a trainer, keeping notes in a journal during the training concerning the trainees' verbal actions and reactions.

\subsubsection{Findings of the analysis}

For the aims of research, the researcher had scheduled three areas of interest: the role of teacher and students in learning process, the concept of knowledge as transferring or process and the content of $\mathrm{RE}$ as truth, value or information.

A. The role of the teacher, the role of students in learning process

\section{Trainer's observation}

- After the work on the first painting itself, participants were asked to comment the lesson process. Even if the group identified that it does not depict a regular or a formal lesson, the main impression was that the teacher doesn't transfer only knowledge, but personal experience, something that has a vital meaning for the students' lives. They are silent listeners, possibly almost frightened, but concentrated and thirsty for what the teachers says. The relation of the teacher to the students, the "sacredness" fascinated 6 out of 8 participants.

- This feeling almost completely changed at the discussion of the second painting. The teacher there was characterized by most of participants as distanced, cold strict and following rules. Students, even if the atmosphere is optimistic and bright, due to the formality of the class cannot succeed in feeling as warm and interested as on the first painting.

- Participants expressed the opinion that the first lesson was experience-based, while the second one seemed to be content-based. At the first painting authenticity lies on the teacher, while in the second on the book.

- Two participants expressed a different opinion, noting that the first teacher is authoritarian and cannot accept any challenge.

Discourse analysis by two independent judges

'In their texts, participants used of course verbs in order to answer to the question: What is the purpose of the lesson from the religion teacher's point of view?

The verbs used were either from the teacher towards the students (e.g. The teacher to transfer, to help, to guide, to propose) or the other way around (e.g. the students to acquire, to discuss, to reflect, to be able to).

- At the first round of texts, 3 participants used verbs from teacher to students, while 5 used verbs referring to students

- At the second round, 6 used from teachers to students, while 2 referring to students

- At the third round, 6 used from teachers to students, while 2 referring to students, but not necessarily the same persons. 
- 2 participants used teacher to student verbs in all three answers, 1 participant used teacher to student at first answer and student referring on the other two, 3 participants used student referring verbs at first answer and teacher to students on second and third, 1 participant student referring at the first answer, teacher to students at the second and student referring at the third, and 1 participant student referring at the two first answers and teacher to students at the third, as shown at the table 1:

Table 1: Verbs orientation per answer

\begin{tabular}{|c|c|}
\hline Participants & $\begin{array}{c}\text { Verbs orientation per answer (T= teacher to } \\
\text { students, M= student centered) }\end{array}$ \\
\hline 2 & $\mathrm{~T}, \mathrm{~T}, \mathrm{~T}$ \\
\hline 1 & $\mathrm{~T}, \mathrm{~S}, \mathrm{~S}$ \\
\hline 3 & $\mathrm{~S}, \mathrm{~T}, \mathrm{~T}$ \\
\hline 1 & $\mathrm{~S}, \mathrm{~T}, \mathrm{~S}$ \\
\hline 1 & $\mathrm{~S}, \mathrm{~S}, \mathrm{~T}$ \\
\hline
\end{tabular}

- That means that from the 8 participants, 2 didn't change the orientation at their answers, while 6 changed in different ways.

B. Is the concept of knowledge a transferring or a process?

Trainer's observation

- Most of the participants (6 out of 8) in discussion accept that the relation of the teacher towards the students is more crucial than the method followed. They come to the conclusion that in the first painting students trust the teacher and believe in what he says, thus they learn.

- Two of the participants recognized successful teaching in both pictures, where at the first they are effective listeners, while at the second they are orchestra members. At the first, those participants identified learning as a cognitive process at the first painting, while a cooperative process at the second, having similar learning outcomes.

\section{Discourse analysis by two independent judges}

- At the first answer, 13 verbs that describe the teacher transferring knowledge were used (ex. teacher to present, to transfer, to guide), while 23 verbs describing knowledge as a process (ex. students to connect, to realize, to explore, to implement) according to the levels of learning (Remembering / Recognition / Understanding, Application, Analysis, Judgment / Evaluation, Creation / Synthesis / Production, and the domains of learning (Cognitive-knowledge, Affective-emotion, Psychomotoraction) (Krathwohl, 2002). In the second answer, 25 verbs for transferring and 3 for process, while at the third answer, 18 for transferring and 9 for process, as shown in Table 2.

- At the first answer, out of the 13 verbs that describe knowledge as a transformation, 3 have cognitive character (ex. teacher to bring, to transfer, to propose), 9 refer to 
skills ( ex. teacher to share, to help, to guide) and one to attitude (teacher to have faith). At the second answer, 7 cognitive, 17 for skills and one (different than on first answer) describes attitude. At the third, 3 are cognitive, and 15 describe skills, as shown in Table 2.

- At the first answer, out of the 23 verbs describing knowledge as a process, 11 are of a cognitive level (ex. students to understand, to be informed, to know), 6 describe skills (ex. students to express, to give meaning, to find out) and 6 describe attitudes (ex. students to feel, to become sensitized, to be concerned). At the second, 1 is cognitive, 1 about skills and 1 of attitudes, while at the third answer, 4 are cognitive, 3 of skills and 2 of attitudes, as shown in Table 2 .

Table 2, verbs used

\begin{tabular}{|c|c|c|c|c|c|}
\hline Answer & Knowledge as & Total & knowledge & skills & attitude \\
\hline 1 & Transformation: & 13 & 3 & 9 & 1 \\
\hline & Process: & 23 & 11 & 6 & 6 \\
\hline 2 & Transformation: & 25 & 7 & 17 & 1 \\
\hline & Process & 3 & 1 & 1 & 1 \\
\hline 3 & Transformation: & 18 & 3 & 15 & - \\
\hline & Process & 9 & 4 & 3 & 2 \\
\hline
\end{tabular}

- At the three answers per person, participants change the verbs they use at every answer. Only one participant uses 1 of the 4 verbs he uses in all three answers, while 3 use 1 or 2 same verbs in two of the answers given. With one exception that all three answers are based on the same ideas, and two that similarities can be found on two of their three answers, most of participants give a different answer to the same question after each part of the training. These changes are not same or similar so than they can be described under a pattern or a scheme.

C. How is religious content used in RE? Is it a truth? A value? An information?

Discourse analysis by two independent judges

- 4 out of the 8 participants, present personal religious conceptions as a truth that in different levels gives meaning to RE and either has to be transferred or be used as a meaning of life or an alternative way in life.

- 1 of those 4 participants keeps the above description in all three answers, while it appears in two out of the three answers to 3 of them. At one case it appears on the first and the second answer, but not at the third, at one on the first and again on the third, at one on the second and the third, while it doesn't on the first.

- 4 out of the 8 participants answer that the lesson deals with religion phenomenon, knowledge about religions and facilitation of personal positive or negative attitude based on religious literacy.

D. The disorientating dilemma 
The process of studying of the two artworks and the discussion signified that the group was more positive (6 out of 8 ) about the learning experience that students appeared to gain in the first painting ("teacher and students form one group", "they seem very concentrated", "teacher spellbinds students"), significantly less in the second one ("the class atmosphere emits coldness" "alienation" "indifferent class under a strict teacher"). Nevertheless, as a teaching and a method, the first painting presents a teachercentered and one-way teaching, while the second one presents group work with the teacher facilitating the process.

Having both paintings on screen, participants were asked the following statement: "In contemporary school, you are called to implement cooperative teaching methods, while it seems that you prefer the first painting ones. Do you feel any contradiction to that?"

- 5 out of 8 participants stated that the way that teacher approaches the students is more important than the method used. The distance, they said, between teacher and students in the first painting is annihilated, while in the second, it makes any method less effective. What matters most is the warmth and the familiarity of the teacher towards students. The first class creates different, deeper experiences to students than the second. They believe to their teacher, as he creates tenderness in the classroom.

- 2 out of 8 participants stated that they prefer the second painting because at the first one the teacher is authoritarian. Not seeming to be able to accept any doubt, he limits the possibility of students to learn, while in the second painting, the teacher does not manipulate students.

- 1 participant stated that both classes depict different successful teaching action. At the first students is the audience, while at the second they are instrument players in an orchestra.

\section{Discussion}

For the certain participants in training research, the role of the teacher is prior and essential at RE lesson. If students' role doesn't come second and minor than the teachers, it is linked to the teacher's role. The active participation to the classroom relies on the teacher theory, following the teacher's teaching character. Regardless the method, the teacher is presented as solely responsible to create the learning experience.

The above-mentioned finding is further investigated to the concept of knowledge. While participants, expressing their statements before the training use more verbs that describe teaching as a process, the balance changes after their positive or negative connection to the art works. The preference of verbs that signify the transformation of skills in comparison to knowledge, can be interpreted as the outcome of teachers use of the current RE curricula.

With just one exception, the answers to the same question in three rounds use different verbs in describing the purpose of RE teaching. The change of the verbs per person, present a fluid description. Neither the descriptions seen in parallel describe 
same or similar purpose. The distance between the description of the purpose of RE in curricula and the teachers' personal theories vary and change, signifying either that $\mathrm{RE}$ teachers are not adequately informed about it, or that they have follow previous curricula descriptions. In any case, it shows there is an assumption of that purpose, that it is open to personal or external influences.

The religious content of RE to be taught as a truth is equally balanced with being used as information, though changing in-between answers of the same persons. Compared to the statement of most of participants, during the disorienting dilemma process, that the method is less important than the teacher's character, presents different models of RE, not only between participants, but also between their personal answers.

Following transformative learning tools in teacher training, research on a small sample of experienced and trained teachers traces multilevel changes at the answers of participants on the same question. Differences at the answers were more than similarities, indicating the need of orienting teacher training at teachers themselves.

This kind of training can facilitate a personal quest towards a personal theory that can help teachers feel safe and secure, primary about their personal religious identity and also about it's relation to RE. It can also offer them ways and tools towards a critical approach of the ambivalent and controversial issues that rapidly arise in contemporary society, faster than their existing knowledge, skills and attitude can consume and use in teaching action.

This research, being experimental and implemented at a small group, cannot offer general conclusions. It is a case study that has limits and pertains to the certain of RE teachers that participated. Nevertheless, it describes a need and offers a first base for a transformative training tool.

\section{References}

Chrysopoulos, Ph. (2016a). New Clash Between Church and Education Minister in Greece, Greece Greek Reporter. Retrieved at 22/2/2019 from https://greece.greekreporter.com/2016/09/21/new-clash-betweenchurch-and-education-minister-in-greece/

Chrysopoulos, Ph. (2016b). Education Minister Makes New Call on State, Church Separation, Greece Greek Reporter. Retrieved at 22/2/2019 from https:/greece.greekreporter.com/2016/10/18/education-ministermakes-new-call-on-state-church-separation/

Grimmitt, M. (1987). Religious Education and Human Development. Great Wakering: McCrimmons.

Jackson, R. (1997). Religious Education: An Interpretative Approach. London: Hodder.

Kazepidis, A.X. (1979). The ideological confusion and the dogmatic saturation of youth in Greek education, Word

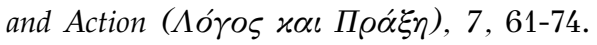

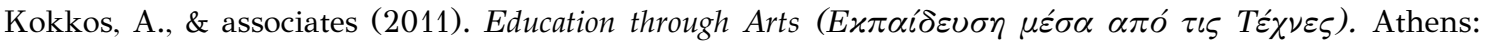
Metaichmio.

Koukounaras Liagkis, M. (2015). Religious education in Greece: a new curriculum, an old issue. British Journal of Religious Education: 37(2), 153-169.

Koukounaras Liagkis, M. (2018). Confessional and non-confessional RE. What would be the meaning of 
the terms today? Greek Journal of Religious Education, 1(1), 1-8.

Krathwohl, D. R. (2002). A Revision of Bloom's Taxonomy: An Overview. Theory into Practice. Retrieved at 20/2/2019 from https://www.depauw.edu/files/resources/krathwohl.pdf

Mezirow J. (1991), Transformative Dimensions of Adult Learning, San Francisco: Jossey-Bass.

Mezirow, J. \& associates (2000). Learning as Transformation. Critical perspectives on a theory in progress. USA: John Willey \& Sons, Inc.

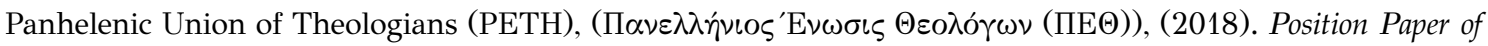

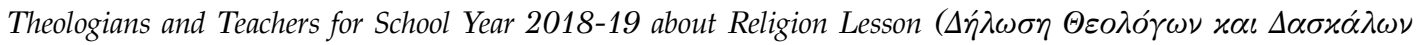

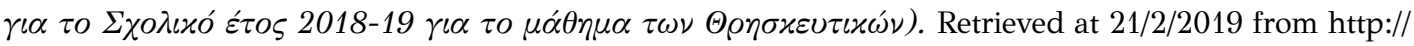
www.petheol.gr/nea/delosetheologonkaidaskalongiatoscholikoetos2018-19giatomathematonthreskeutikon

Perkins, D. (1994). The intelligent eye, USA: The Getty Center for Education in Arts.

Stavropoulos, A. M., \& Koumaropoulos, S. (1998). The work of the Religion teacher and the Religion Lesson

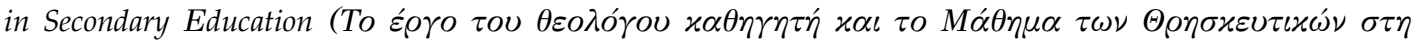

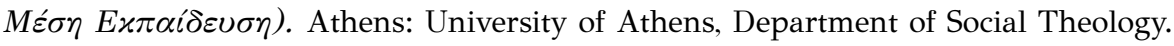

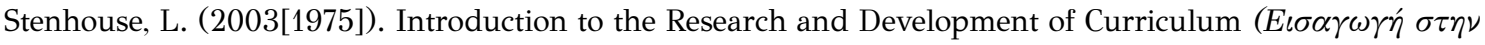

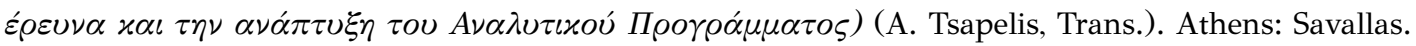

Wright, A. (2004). Religion, education and post-modernity. London: RoutledgeFalmer.

Wright, A. (2007). Critical Religious Education, Multiculturalism and the Pursuit of Truth. Cardiff: University of Wales Press.

Vassalou, E. (2016). The Curriculum of Arigatou Global Network of Religions for Children (GNRC) as a

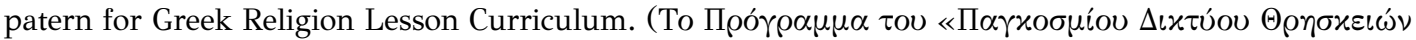



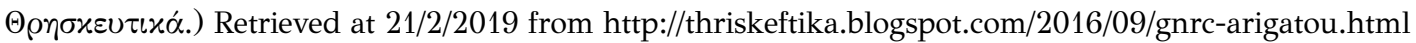




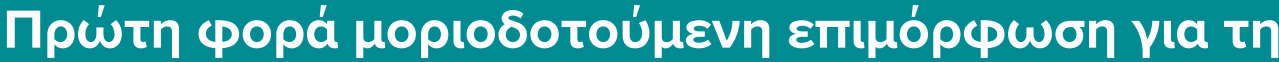

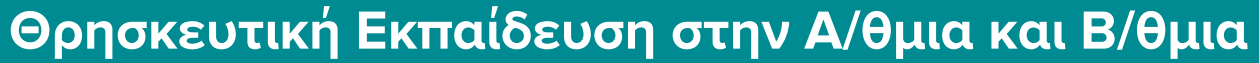

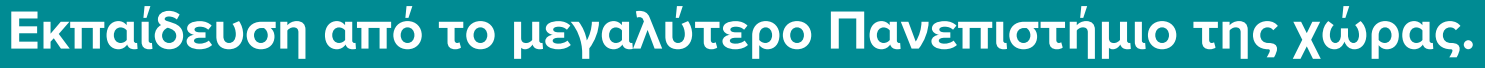

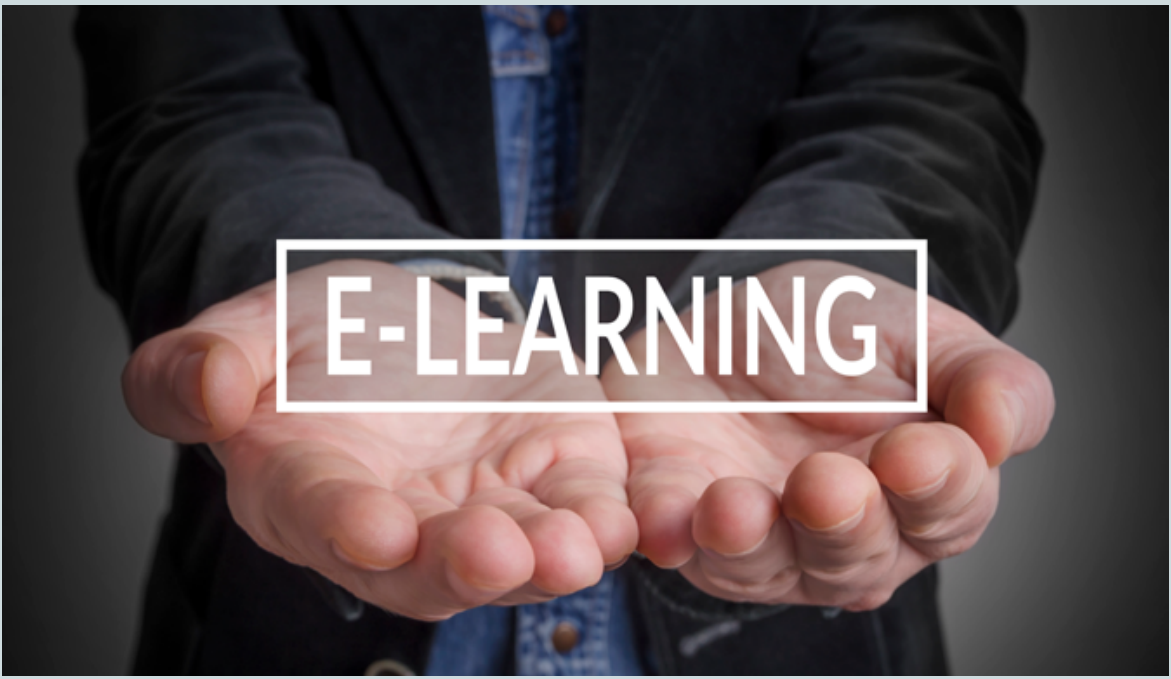

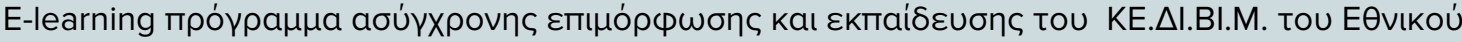

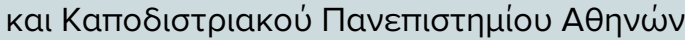

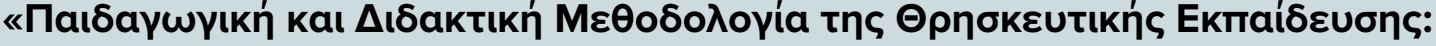

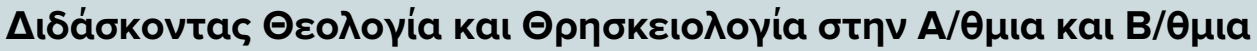

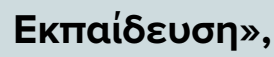

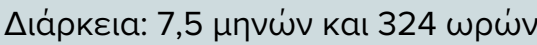

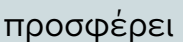

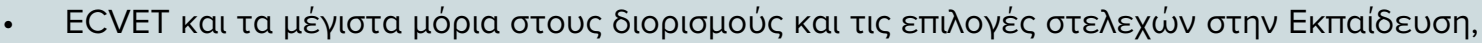

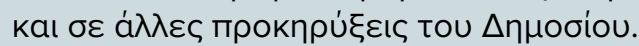

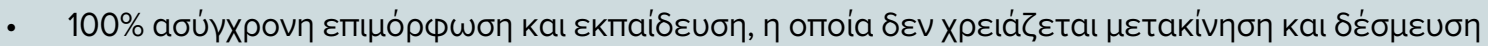

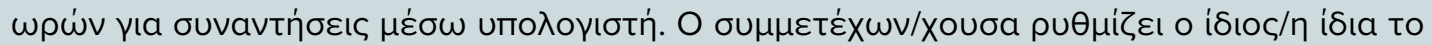

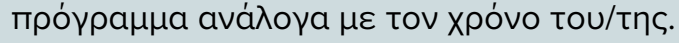

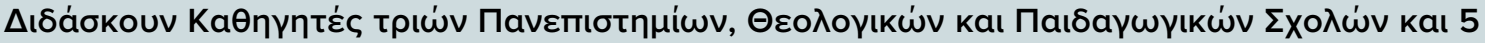

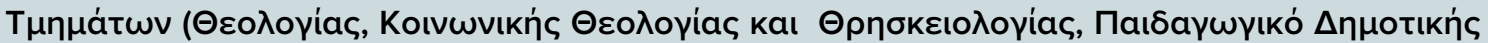

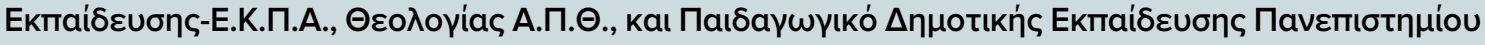
Alyaíou).

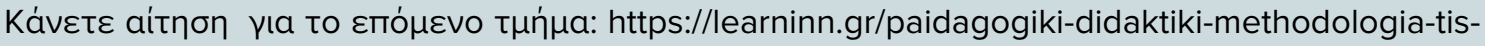
thriskeytikis-ekpaideysis/

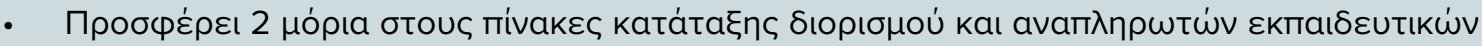

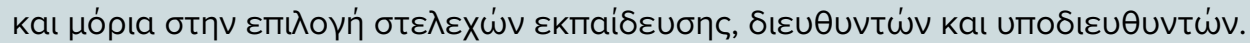

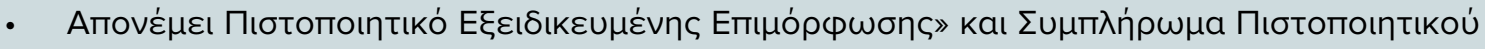
Europass.

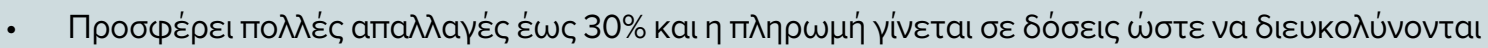
ó̀oı. 